\title{
Performance and intestinal health of broilers inoculated with nalidixic acid- resistant Salmonella Typhimurium and treated with organic acids
}

\author{
Tatiane Martins Rocha ${ }^{1}$, Maria Auxiliadora Andrade ${ }^{2}$, Eliete Silva e Souza ${ }^{1}$, José Henrique \\ Stringhini ${ }^{2}$, Marcos Barcellos Café ${ }^{2}$, Cíntia Silva Minafra e Rezende ${ }^{2}$, Regiani Nascimento \\ Gagno Pôrto ${ }^{2}$
}

\footnotetext{
1 Programa de Pós-Graduação em Ciência Animal, UFG.

${ }^{2}$ Escola de Veterinaria, Universidade Federal de Goias, Goiânia.
}

\begin{abstract}
An experiment with 630 one-day-old chicks experimentally inoculated with Salmonella Typhimurium was performed to evaluate the effects of an organic acid blend (benzoic, fumaric and 2-hydroxi-4-methylltio-butanoic HMTBa) on intestinal health and performance. The experimental challenge with Salmonella Typhimurium occurred in two different routes of administration: via crop on the first day after hatching, and via feed, offered from seven to 14 days of age. These groups were treated with organic acids in a $3 \times 2$ (agent versus acid) factorial arrangement. Chicks treated with organic acids had higher weight gain, mean live weight and better feed conversion at 14 days of age, and higher weight gain at 28 days of age. Chicks treated with organic acids inoculated via crop had higher duodenum villi height than animals of the control group. Jejunum villi were higher in chicks of the negative control group compared with birds supplemented with organic acids. Small intestine $\mathrm{pH}$ in chicks of the inoculated group was lower compared with control group throughout the trial period. HMTBa acid in the dosage of $0.4 \%$ improves intestinal health and performance when nalidixic acid resistant Salmonella Typhimurium is experimentally inoculated.
\end{abstract}

Key Words: birds, contamination, control feed, conversion, salmonellosis

\section{Introduction}

For the last years, paratyphic infections have been classified as of high risk for both Brazilian poultry industry and public health and Salmonella enterica subsp. enterica sorovar Typhimurium has been considered one of the most important of these diseases. Then, Salmonella Typhimurium control in poultry facilities is essential to avoid trading restrictions and to minimize the financial hazards of the Brazilian Industry, which developed some criteria to control these pathogens until the period before slaughtering and processing.

The presence of a contaminated stock, environment and feeds is the major ways to introduce Salmonella into the production system are (Tessari et al., 2003). By this means, contamination of diet, silos or feeders enables the transmission of Salmonella to the bird stock (Berends et al., 1996). Dibner \& Buttin (2002) stated that organic acids can reduce Salmonella contamination and, consequently, minimize the subclinical infections in birds, and contribute to improve nutrient absorption, increasing the expression of the digestive and immune system potentialities.

It is hard to compare results among experiments that tested organic acids in blends without considering their particular way of action. Benefits depend on the organic acid which is presented in blends and their doses, so, the correct use of these compounds requires more information about their way of action on the different gastrointestinal pathogens.

Because of this necessity to control the pathogens, this experiment was proposed and conducted to observe the activity of a blend of organic acids (benzoic, fumaric and 2-hidroxi-4-metiltiobutanoic) on the performance and intestinal health of broilers inoculated with Salmonella enterica subsp. enterica sorovar Typhimurium.

\section{Material and Methods}

Chicks were allotted in the Avian Diseases Experimental Section with proper isolation facilities for the study of these pathogens. These facilities were built to assure that birds would not be contaminated, blocking insects, rodents, wild birds and people. The contact established between the chicks and people was restricted to individuals particularly dressed and with specific biosecurity care established for this experiment. The necropsy of the chicks considered negative control confirmed the absence of Salmonella. 
A total of 630 day-old chicks was distributed into six treatments and seven replicates of 15 birds each were used for a period of 28 days. A completely randomized design was used in a $3 \times 2$ factorial arrangement, with three inoculated agents $(0.85 \%$ saline solution as a placebo, and Salmonella enterica subsp. enterica sorovar Typhimurium inoculated in the crop and via feed) and the use of the organic acids proposed ( 0 or $4 \mathrm{~kg} / \mathrm{T}$ of the organic acid blend) (Table 1).

The inoculum was prepared as described by Fernández et al. (2001) and nalidixic acid resistant Salmonella Typhimurium was obtained from the broiler samples used by Rezende et al. (2008) in her experiment. Feed was formulated based on corn-soybean meal according to recommendations by Rostagno et al. (2005) and were offered ad libitum. The organic acid blend was composed of benzoic acid (22.44\%), fumaric acid (41.34\%) and 2-hidroxi 4-methyltiobutanoic acid (28.40\%), offered to the birds through the ration during all the experimental period. The contaminated feed was made at the dose of $0.4 \%$ of total ration. In the group challenged via ration, Salmonella inoculum $(0.5 \mathrm{~mL}$ of the inoculum $/ 500 \mathrm{~g}$ feed) was prepared by means of manual homogenization in the plastic bags.

Chicks and feed were weighed on the $1^{\text {st }}, 7^{\text {th }}, 14^{\text {th }}$ and 21 st days of age mean body weight, weight gain, feed intake and feed conversion were calculated. On the $7^{\text {th }}, 14^{\text {th }}$ and $21^{\text {st }}$ and $28^{\text {th }}$ days of age, chicks fasted for four to six hours before the necropsy for elimination of the chime. One bird per experimental unit was weighed and necropsied. The small intestine relative weight and height of each bird was established.

Samples of duodenum and jejunum were collected for histomorphometrical evaluation and processed, following the standard methodology by Luna (1968), at 7, 14 and 28 days of age. At the same ages, the small intestine and jejunum content was collected from one bird per replicate and the $\mathrm{pH}$ values of the samples were determined according to the methodology used by Silva et al. (2000).

Results were submitted to ANOVA and means compared by Tukey test at $5 \%$ probability using SAS (2004).

\section{Results and Discussion}

Organic acid supplementation resulted in better results of feed conversion $(\mathrm{P}<0.05)$ compared with control treatments (Table 2). These results are in accordance with Partanen \& Mroz (1999), who claimed that organic acids, associated with nutritional assessments, handling and biosecurity, can maintain intestinal health, which can affect feed conversion. Birds inoculated with Salmonella Typhimurium had worst feed conversion compared with the control group (Table 2), for both ways of inoculation tested.

Table 1 - Experimental design of the treatment

\begin{tabular}{lcc}
\hline S. Typhimurium challenge and the method of inoculation & Organic acids & Number of chick \\
\hline No - saline solution at $0.85 \%$ & No & 105 \\
No - saline solution at $0.85 \%$ & Yes & 105 \\
Yes, into the crop on the $1^{\text {st }}$ day of age & No & 105 \\
Yes, into the crop on the $1^{\text {st }}$ day of age & Yes & No \\
Yes, through feed from $7^{\text {th }}$ to $14^{\text {th }}$ days of age & Yes & 105 \\
Yes, through feed from $7^{\text {th }}$ to $14^{\text {th }}$ days of age & $5.0 \times 10^{2} \mathrm{CFU}$ CFU & 105 \\
\hline
\end{tabular}

Table 2 - Mean weight, weight gain, feed intake and feed conversion for broilers from 1 to 14 days of age inoculated with Salmonella Typhimurium, and treated with an organic acid blend

\begin{tabular}{|c|c|c|c|c|c|}
\hline & $\begin{array}{c}\text { Starter } \\
\text { weight }(\mathrm{g})\end{array}$ & $\begin{array}{l}\text { Mean weight at } \\
14 \text { days of age }(\mathrm{g})\end{array}$ & $\begin{array}{l}\text { Weight } \\
\text { gain }(\mathrm{g})\end{array}$ & $\begin{array}{c}\text { Feed } \\
\text { intake }(g)\end{array}$ & $\begin{array}{c}\text { Feed conversion } \\
(\mathrm{g} / \mathrm{g})\end{array}$ \\
\hline & \multicolumn{5}{|c|}{ Organic acids (A) } \\
\hline Without & 42.79 & 431.02 & 388.23 & 490.38 & $1.303 \mathrm{~b}(1)$ \\
\hline \multicolumn{6}{|c|}{ Inoculated agent (S) } \\
\hline Placebo & 42.68 & 455.14 & 402.45 & $402.49 b$ & $1.012 \mathrm{a}$ \\
\hline \multicolumn{6}{|c|}{ Variation factors $(\%)$} \\
\hline Organic acids $(\mathrm{OA})$ & $<0.001$ & 0.032 & 0.030 & 0.351 & 0.028 \\
\hline Inoculated agents (IA) & $<0.001$ & 0.081 & 0.079 & $<0.001$ & $<0.001$ \\
\hline $\mathrm{OA} \times \mathrm{IA}$ & $<0.001$ & 0.036 & 0.035 & 0.850 & 0.064 \\
\hline CV (\%) & 0.39 & 8.09 & 8.96 & 3.99 & 14.18 \\
\hline
\end{tabular}

\footnotetext{
${ }^{1}$ Distinct letters on the column indicate difference (Tukey, $\left.5 \%\right) ;{ }^{2}$ ST-crop:Salmonella Typhimurium inoculated via crop; ${ }^{3}$ ST-ration: Salmonella Typhimurium inoculated
} via ration. $\mathrm{CV}=$ coefficient of variation. 
The evaluation of the interaction between inoculated agents and organic acids (Table 3 ) showed the best mean weight and weight gain from 1 to 14 days of age for chicks inoculated with the bacteria via crop and treated with the organic acid blend. Le Ny (2005) reported that organic acids can, primarily, inhibit the pathogen establishment because of the intracellular $\mathrm{pH}$ reduction, which affects DNA replication and protein synthesis.

The group inoculated via crop with Salmonella Typhimurium $(\mathrm{P}<0.05)$ showed lower values for both mean weight at 14 days of age and weight gain from 1 to 14 days of age compared with the chicks inoculated via ration (Table 3). This result can be explained by the chick age at inoculation, because the birds were challenged via crop on the first day of age, and via ration at seven days of age. The age is an important factor for the microbiota composition, and in younger animals the bacteria can easily colonize the intestines. The microbiota is formed by the contact of the chick with the microorganisms presented in the hatching chamber, in the transportation boxes or in the facilities and equipments. Desmidt et al. (1997) reported that, by aging, the specific and non-specific immunological defense mechanisms are capable of impairing Salmonella infection, which can be attributed to the development of the cellular and humoral immune system on the first days of life. Beal et al. (2004) orally challenged chicks at one, three and six weeks of age with $10^{8} \mathrm{CFU}$ of Salmonella Typhimurium and verified that older birds, with a welldeveloped immune system, showed a faster response to eliminate the inoculated agents. Barrow (2000) confirmed that the invasion mechanism and capacity of Salmonella depends on the age of bird and the way the agent contaminates the organs.

By evaluating chick performance from 1 to 28 days of age (Table 4), it was verified that chicks that received
Salmonella, via both inoculation ways, presented best feed conversion $(\mathrm{P}<0.05)$ and, on the other hand, worse feed conversion $(\mathrm{P}<0.05)$ when compared with the control birds. Similar results were observed by Xie et al. (2000), who verified significant performance reduction when birds were inoculated with a Salmonella Typhimurium lipopolysaccharide (LPS).

Birds treated with the organic acid blend showed increased efficiency in weight gain from 1 to 28 days of age compared with the control treatment (Table 4). Organic acids can reduce colonization by Salmonella (Van Immerseel et al., 2004) and increase performance (Snow et al., 2004; Rafacz-Livingston et al., $2005 \mathrm{a}, \mathrm{b})$. In the evaluation of the activity of organic acids on broiler performance, Skinner et al. (1991) found a positive effect of the fumaric acid $(0.125 \%)$ until 49 days of age with linear reduction of mortality until $0.5 \%$ of the diet. Viola \& Vieira (2007) tested different mixtures of organic acids in diets and verified that the body weight gain was not affected by treatments.

In this study, chicks inoculated via crop at 7,14 and 28 days of age which did not receive organic acids showed lower villus height in the duodenum compared with the group that received organic acids (Table 5). At 28 days of age, jejunum villi presented lower heights $(\mathrm{P}<0.05)$ compared with treatments which did not receive organic acids. These results suggest that the lower the contamination by non-desirable microorganisms in the intestine, the higher the villus height. Intestinal integrity and health can be related to the results obtained, because broilers which received organic acids had significant results for feed conversion at 14 days of age and weight gain at 28 days of age when compared with the group that did not receive the organic acid blend.

According to Daskiran et al. (2004) and Leeson et al. (2005), acidifiers help the intestinal integrity maintenance

Table 3 - Development of interaction between inoculated agents and organic acids used for mean weight at 14 days of age and weight gain from 1 to 14 days of age for broilers inoculated with Salmonella Typhimurium via crop and via ration, treated with an organic acid blend

\begin{tabular}{|c|c|c|c|}
\hline \multirow[b]{3}{*}{ Organic acids } & \multicolumn{3}{|c|}{ Mean weight at 14 days of age $(\mathrm{g})$} \\
\hline & \multicolumn{3}{|c|}{ Inoculated agents } \\
\hline & Placebo & ST-crop ${ }^{2}$ & ST-ration \\
\hline Absence & $441.02 \mathrm{Aab}$ & $393.44 \mathrm{Bb}$ & $458.60 \mathrm{Aa}$ \\
\hline \multirow[t]{2}{*}{ Presence } & $449.26 \mathrm{Aa}$ & $460.16 \mathrm{Aa}$ & $457.62 \mathrm{Aa}$ \\
\hline & \multicolumn{3}{|c|}{$\begin{array}{l}\text { Weight gain from } 1 \text { to } 14 \text { days of age }(\mathrm{g}) \\
\text { Inoculated agents }\end{array}$} \\
\hline Organic acids & Placebo & ST-crop ${ }^{2}$ & ST-ration \\
\hline Absence & $397.98 \mathrm{Aab}$ & $350.49 \mathrm{Bb}$ & $416.21 \mathrm{Aa}$ \\
\hline Presence & $402.92 \mathrm{Aa}$ & $417.87 \mathrm{Aa}$ & $415.27 \mathrm{Aa}$ \\
\hline
\end{tabular}


Table 4 - Mean weight, weight gain, feed intake and feed conversion of broilers from 1 to 28 days of age inoculated with Salmonella Typhimurium, and treated with an organic acid blend

\begin{tabular}{|c|c|c|c|c|}
\hline & Starter weight $(\mathrm{g})$ & Weight gain $(\mathrm{g})$ & Feed intake $(\mathrm{g})$ & Feed conversion $(\mathrm{g} / \mathrm{g})$ \\
\hline & \multicolumn{4}{|c|}{ Organic acids (A) } \\
\hline Without & $1125.10 \mathrm{~b}(1)$ & $1082.31 \mathrm{~b}$ & 1513.90 & 1.534 \\
\hline \multirow[t]{2}{*}{ With } & $1201.13 \mathrm{a}$ & $1158.80 \mathrm{a}$ & 1574.46 & 1.505 \\
\hline & \multicolumn{4}{|c|}{ Inoculated agent $(\mathrm{S})$} \\
\hline Placebo & 1155.16 & 1112.48 & $1406.75 b$ & $1.398 \mathrm{a}$ \\
\hline ST-crop ${ }^{2}$ & 1170.25 & 1127.63 & $1599.55 \mathrm{a}$ & $1.565 \mathrm{~b}$ \\
\hline Organic acids (OA) & 0.001 & 0.001 & 0.069 & 0.176 \\
\hline Inoculated agents (IA) & 0.847 & 0.846 & $<0.001$ & $<0.001$ \\
\hline $\mathrm{OA} \times \mathrm{IA}$ & 0.194 & 0.190 & 0.173 & 0.456 \\
\hline CV (\%) & 5.97 & 6.20 & 6.79 & 4.60 \\
\hline
\end{tabular}

${ }^{1}$ Distinct letters on the column indicate difference (Tukey, $5 \%$ ); ${ }^{2}$ ST-crop: Salmonella Typhimurium inoculated via crop; ${ }^{3}$ ST-ration: Salmonella Typhimurium inoculated via ration. $\mathrm{CV}=$ coefficient of variation.

Table 5 - Villus height and crypt depth of duodenum and jejunum of chicks inoculated with Salmonella Typhimurium via crop

\begin{tabular}{|c|c|c|c|c|c|c|}
\hline & \multicolumn{2}{|c|}{7 days } & \multicolumn{2}{|c|}{14 days } & \multicolumn{2}{|c|}{28 days } \\
\hline & \multicolumn{6}{|c|}{ Duodenum } \\
\hline & Height $(\mu \mathrm{m})$ & Depth $(\mu \mathrm{m})$ & Height $(\mu \mathrm{m})$ & Depth $(\mu \mathrm{m})$ & Height $(\mu \mathrm{m})$ & Depth $(\mu \mathrm{m})$ \\
\hline Negative control + acid $^{b}$ & $975.32 \mathrm{a}$ & 187.49 & $931.10 \mathrm{a}$ & 181.13 & $1063.07 \mathrm{~b}$ & $263.76 \mathrm{a}$ \\
\hline ST- crop & $851.81 \mathrm{~b}$ & 168.04 & $566.15 b$ & 174.44 & $876.80 \mathrm{c}$ & $175.06 \mathrm{bc}$ \\
\hline ST- crop + acid $^{d}$ & $1021.88 \mathrm{a}$ & 198.16 & $1197.04 \mathrm{a}$ & 249.03 & $1109.60 \mathrm{~b}$ & $218.00 \mathrm{~b}$ \\
\hline \multirow{3}{*}{$\mathrm{P}$} & \multicolumn{6}{|c|}{ Jejunum } \\
\hline & \multicolumn{2}{|c|}{7 days } & \multicolumn{2}{|c|}{14 days } & \multicolumn{2}{|c|}{28 days } \\
\hline & Height $(\mu \mathrm{m})$ & Depth $(\mu \mathrm{m})$ & Height $(\mu \mathrm{m})$ & Depth $(\mu \mathrm{m})$ & Height $(\mu \mathrm{m})$ & Depth $(\mu \mathrm{m})$ \\
\hline Negative control $^{\mathrm{a}}$ & $602.89 \mathrm{~b}$ & $237.43 \mathrm{a}$ & 575.60 & 170.42 & $613.31 \mathrm{~b}$ & 139.72 \\
\hline Negative control + acid $^{b}$ & $718.77 \mathrm{a}$ & $111.00 \mathrm{~b}$ & 585.70 & 170.67 & $823.93 \mathrm{a}$ & 131.84 \\
\hline
\end{tabular}

Distinct letters on the same column and age differ by Tukey test (5\%).

a Negative control; ${ }^{b}$ Negative control of the acid; ${ }^{\mathrm{c}}$ Inoculated via crop; ${ }^{\mathrm{d}}$ Inoculated via crop and treated with acid.

$\mathrm{CV}=$ coefficient of variation.

due to the reduced microbiological challenges of the mucosa, increasing the capacity of feed use by the animals and reducing the maintenance wastes of intestinal tissues. According to Salazar et al. (2008), the way of action of the organic acids in the intestinal epithelium can reduce the pathogenic bacteria population because of their capacity to decrease intestinal medium $\mathrm{pH}$, which hampers the bacteria adhesion to the mucosa, reducing epithelium damage. In the same way, Maiorka et al. (2004) observed that the presence of trophic agents, such as nutrients in the intestinal lumen stimulate the mucosa development, originating a mitotic process, in addition to increasing the number of cells and the villus height.

At 21 days of age, the small intestine weight was lower $(\mathrm{P}<0.05)$ with the organic acid addition (Table 6$)$.
Higher weight $(\mathrm{P}<0.05)$ was observed at 7,14 and 28 days of age, for treatments inoculated with Salmonella, in all the inoculation ways compared with the placebo group.

The higher small intestine weight in the challenged groups does not seem to be related to a better intestinal health state or nutrient absorption capacity. This fact was confirmed by the data presented in Table 5 because at 7 , 14 , and 28 days of age, chicks inoculated via crop showed mean values $(\mathrm{P}<0.05)$ for duodenum villus height compared with the other analyzed groups. Another explanation is that the finding might be due to the Salmonella activity in the intestine, because microbiological challenges can result in intestinal inflammation and, sometimes, necrosis of the tissues can occur (Apajalahti, 2005). 
Table 6 - Small intestine weight and height of broilers at 14, 21 and 28 days of age inoculated with Salmonella Typhimurium via crop and via ration and treated with an organic acid blend

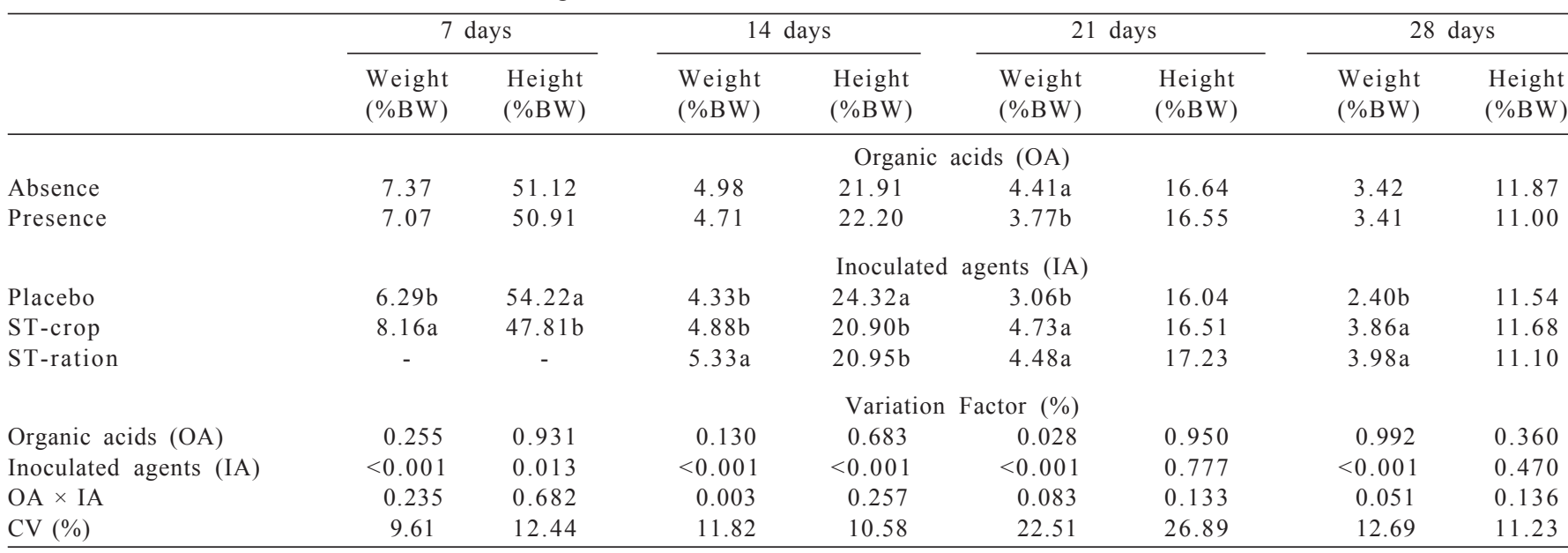

Distinct letters on the same column indicate differences by Tukey test $(5 \%)$. CV $=$ Coefficient of variation. $\% \mathrm{WG}=$ bird weight gain

The group inoculated with placebo had higher small intestine length $(\mathrm{P}<0.05)$ compared with the groups inoculated with the pathogen via both tested ways at 7 and 14 days of age (Table 6). This fact can be due to Salmonella infection, which caused tissue and cell disorders which reduced the absorption area and worsened feed conversion at 7 and 14 days of age.

Through the analysis of the interaction between inoculated agents and organic acids of the small intestine weight at 14 days of age (Table 7), it was possible to verify that the small intestine weight of chicks that were inoculated via ration and received the organic acid blend was lower $(\mathrm{P}<0.05)$ compared with the birds that did not receive the organic acids in the diet. This is a possible result of the organic acids activity against the pathogenic agent.

The inclusion of the organic acid blend did not affect small intestine $\mathrm{pH}$ or ceca content $(\mathrm{P}<0.05)$ during the studied periods (Table 8). It was observed that the small intestine $\mathrm{pH}$ was statistically higher in the placebo group when compared with the inoculated chicks. The ceca $\mathrm{pH}$ was statistically different at 7 (Table 8 ) and 21 days of age (Table 9) and the placebo group showed the highest values.

Table 7 - Development of statistical interaction for small intestine weight at 14 days of age for broilers inoculated with Salmonella Typhimurium via crop and via ration and treated with organic acids blend

\begin{tabular}{lccc}
\hline & \multicolumn{3}{c}{ Inoculated agents } \\
\cline { 2 - 4 } & Placebo & ST-crop & ST-ration \\
\hline Organic acids in ration & $4.43 \mathrm{Ab}$ & $4.63 \mathrm{Ab}$ & $5.89 \mathrm{Aa}$ \\
Absence & $4.23 \mathrm{Aa}$ & $5.13 \mathrm{Aa}$ & $4.76 \mathrm{Ba}$ \\
Presence & & & \\
\hline Different lowercase letters on the column (row) indicate statistical difference by \\
Tukey test $(5 \%)$.
\end{tabular}

Table 8 - Values of small intestine and ceca content $\mathrm{pH}$ of broilers at 7,21 and 28 days of age inoculated with Salmonella Typhimurium via crop and via ration and treated with a blend of organic acids

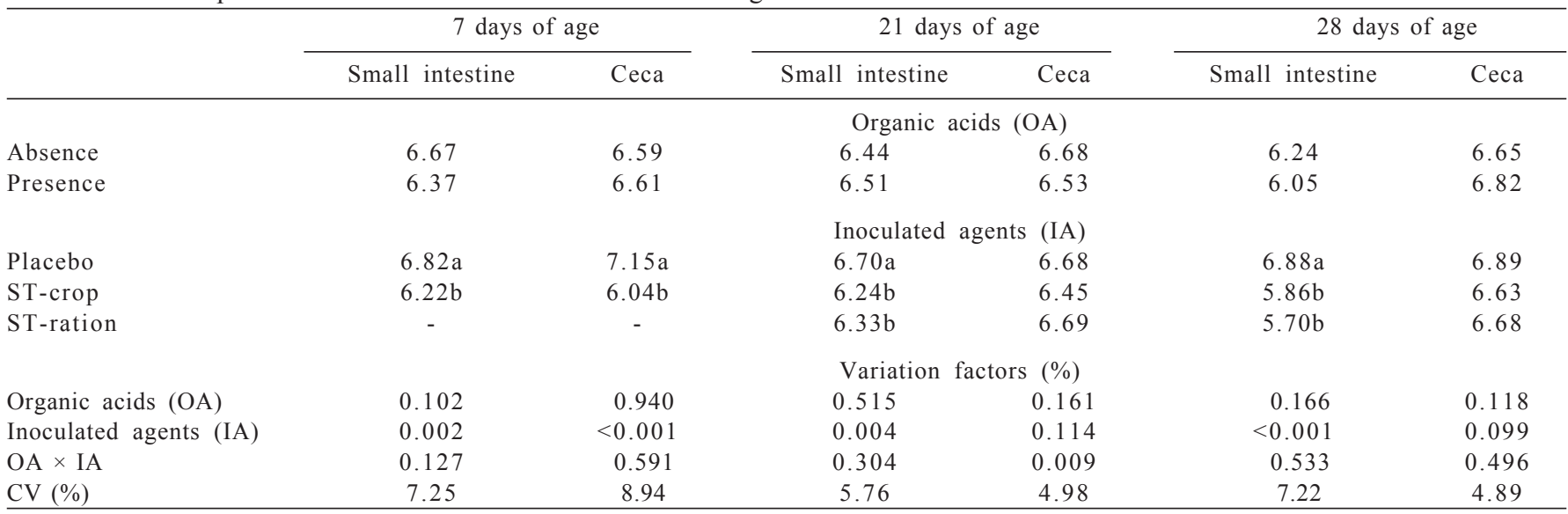

Distinct letters in the column and row indicate statistical differences by Tukey test $(5 \%)$. 
Table 9 - Development of statistical interaction between inoculated pathogenic agent and the use of organic acid blend in ration for ceca content $\mathrm{pH}$ at 21 days of age in chicks inoculated with Salmonella Typhimurium

\begin{tabular}{lccc}
\hline & \multicolumn{3}{c}{ Inoculated agents } \\
\cline { 2 - 4 } Organic acids & Placebo & ST-crop & ST-ration \\
\hline Without & 6.53 & 6.70 & 6.81 \\
WIth & $6.83 \mathrm{a}$ & $6.21 \mathrm{~b}$ & $6.56 \mathrm{ab}$ \\
\hline
\end{tabular}

Different lowercase letters on the column (row) indicate statistical difference by Tukey test $(5 \%)$

It is likely that $S$. Typhimurium determined higher intestinal fermentation and, as a consequence, reduced the $\mathrm{pH}$. Lower $\mathrm{pH}$ indicates fermentation and production of volatile fatty acids (Huang et al., 2006). In a similar way, Chambers et al. (1997) verified that the samples with the highest $\mathrm{pH}$ values, in CFU of Salmonella were also the ones with lowest cecal $\mathrm{pH}$.

\section{Conclusions}

Organic acids blend (benzoic, fumaric and 2-hidrox4-methyltiobutanoic), offered at $0.4 \%$ in ration increases performance and intestinal health for broilers challenged with Salmonella Typhimurium between 1 and 28 days of age.

\section{Acknowledgements}

The authors thank CNPq and Novus do Brasil for financial and material support and Karla Avanço for helping them translate this article.

\section{References}

APAJALAHTI, J. Comparative gut microflora, metabolic challenges, and potential opportunities. Journal of Applied Poultry Research, v.14, p.444-453, 2005.

BARROW, P.A. The paratyphoid salmonellae. Review in Science and Technology, v.9, n.2, p.351-375, 2000.

BEAL, R.K.; WIGLEY, P.; POWERS, C. et al. Age at primary infection with Salmonella enterica serovar Typhimurium in the chicken influences persistence of infection and subsequent immunity to re-challenge. Veterinary Immunology and Immunopathology, v.100, p.151-164, 2004

BERENDS, B.R.; URLING, H.A.P.; SNIJDERS, J.M.A. et al. Identification and quantification of risk factors in animal management and transport regarding Salmonella sp. in pigs. International Journal of Food Microbiology, v.30, p.37-53, 1996.

CHAMBERS, J.R.; SPENCER, J.L.; MODLER, H.W. The influence of complex carbohydrates on Salmonella typhimurium colonization, $\mathrm{pH}$, and density of broiler ceca. Poultry Science, v.76, p.445-451, 1997
DASKIRAN, M.; TEETER, R.G.; VANHOOSER, S.L. et al. Effect of dietary acidification on mortality rates, general performance, carcass characteristics, and serum chemistry of broilers exposed to cycling high ambient temperature stress. Journal Applied Poultry Research, v.13, p.605-613, 2004.

DESMIDT, M.; DUCALETTE, R.; HAESEBROUCK, F. Pathogenesis of Salmonella Enteritidis phage types four after experimental infection of young chickens. Veterinary Microbiology, v.56, p.99-109, 1997.

DIBNER, J.J.; BUTTIN, P. Use of organic acids as a model to study the impact of gut microflora on nutrition and metabolism. Journal of Applied Poultry Research, v.11, p.453-463, 2002.

FERNÁNDEZ, A.; LARA, C.; LOSTE, A. et al. Control of Salmonella enteritidis phage types 4 experimental infection by fosfomycin in newly hatched chicks. Comparative Immunology, Microbiology \& Infectious Disease, v.24, p.207-216, 2001.

HUANG, D.S.; LI, D.F.; XING, J.J. et al. Effects of feed particle size and feed form on survival of Salmonella typhimurium in the alimentary tract and cecal $S$. typhimurium reduction in growing broilers. Poultry Science, v.8, p.831-836, 2006.

LE NY, P. Use of organic acids in poultry production. Mode of action and applications. In: FÓRUM INTERNACIONAL DE AVICUlturA, 1., Foz do Iguaçu. Anais... Campinas: Editora Animal World, 2005. p.158-165.

LEESON, S.; NAMKUNG, H.; ANTONGIOVANNI, M. et al. Effect of butyric acid on the performance and carcass yield of broiler chickens. Poultry Science, v.84, p.1418-1422, 2005.

LUNA, L.G. Manual of histologic staining methods of the Armed Forces Institute of Pathology. 3.ed. New York: McGraw-Hill, 1968. p.258.

MAIORKA, A.; SANTIN, A.M.E.; BORGES, S.A. et al. Emprego de uma mistura de ácidos fumárico, lático, cítrico e ascórbico em dietas iniciais de frangos de corte. Archives of Veterinary Science, v.9, n.1, p.31-37, 2004.

PARTANEN, K.; MROZ, Z. Organic acids for performance enhancement in pig diets. Nutrition Research Reviews, v.12, n.1, p.117-145, 1999.

RAFACZ-LIVINGSTON, K.A.; PARSONS, C.M.; JUNGKT, R.A. The effects of various organic acids on phytate phosphorus utilization in chicks. Poultry Science, v.84, p.1356-1362, $2005 \mathrm{a}$

RAFACZ-LIVINGSTON, K.A.; MARTINEZ-AMEZCUA, C.; PARSONS, C.M. et al. Citric acids improves phytate phosphorus utilization in crossbred and commercial broiler chicks. Poultry Science, v.84, p.1370-1375, 2005b.

REZENDE, C.S.M.; MESQUITA, A.J.; ANDRADE, M.A. et al. Ácido acético em rações de frangos de corte experimentalmente contaminados com Salmonella Enteritidis e Salmonella Typhimurium. Revista Brasileira de Saúde e Produção Animal, v.9, n.3, p.516-528, 2008.

ROSTAGNO, H.S.; ALBINO, L.F.T.; DONZELE, J.L. et al Composição de alimentos e exigências nutricionais de aves e suínos. (Tabelas Brasileiras). Viçosa, MG: Imprensa Universitária, 2005. 186p.

SALAZAR, P.C.R.; ALBUQUERQUE, R.; TAKEARA, P. et al. Efeito dos ácidos lático e butírico, isolados e associados, sobre o desempenho e morfometria intestinal em frangos de corte. Brazilian Journal of Veterinary Research and Animal Science, v.45, n.6, p.463-471, 2008.

SAS/IML 9.1 User's guide. Cary: SAS Institute Inc., Cary: 2004 $1037 \mathrm{p}$.

SILVA, E.N.; TEIXEIRA, A.S.; FIALHO, E.T. et al. Efeitos dos probióticos e antibióticos sobre as vilosidades e $\mathrm{pH}$ do trato gastrointestinal de frangos de corte. Ciência e Agrotecnologia, v.24 (edição especial), p.163-173, 2000.

SKINNER, J.T.; IZAT, A.L.; WALDROUP, P.W. Research note:fumaric acid enhances performance of broiler chickens. Poultry Science, v.70, n.6, p.1444-1447, 1991. 
SNOW, J.L.; BAKER, D.H.; PARSONS, C. Phytase, citric acid, and 1-a-hidroxycholecalciferol improve phytate phosphorus utilization in chicks fed a corn-soybean meal diet. Poultry Science, v.83, p.1187-1192, 2004.

TESSARI, E.N.C.; CARDOSO, A.L.S.P.; CASTRO, A.G.M. et al. Incidência de Salmonella spp. em pintos de corte recém-nascidos. Arquivos do Instituto Biológico, v.70, n.3, p.279-281, 2003.

VAN IMMERSEEL, F.; FIEVES, V.; BUCK, J. et al. Microencapsulated short-chain fatty acids in feed modify colonization and invasion early after infection with Salmonella enteritidis in young chickens. Poultry Science, v.83, p.69-74, 2004.

VIOLA, E.S.; VIEIRA, S.L. Suplementação de acidificantes orgânicos e inorgânicos em dietas para frangos de corte: desempenho zootécnico e morfologia intestinal. Revista Brasileira de Zootecnia, v.36, n.4, p.1097-1104, 2007.

XIE, H.; RATH, N.C.; HUFF, G.R. et al. Effects of Salmonella typhimurium lipopolysaccharide on broiler chickens. Poultry Science, v.79, p.33-40, 2000. 